\title{
Kontestasi atas Otoritas Teks Suci Islam di Era Disrupsi: Bagaimana Kelas Menengah Muslim Indonesia Memperlakukan Hadis melalui Media Baru
}

\author{
Rizqa Ahmadi \\ Institut Agama Islam Negeri Tulungagung, Jawa Timur, 66221, Indonesia \\ rizqa.uns@gmail.com \\ 081333130002
}

ARTICLE INFO

Article history:

Received : 2019-01-30

Revised : 2019-03-25

Accepted : 2019-05-23

Keywords:

Hadith authority,

disruption era,

middle-class moslem,

new media.

Kata kunci:

Otoritas hadis,

era disrupsi,

kelas menengah Muslim, media baru.

\section{ABSTRACT}

This paper was written to become a preliminary record of the hadith debate as one of the sacred texts of Islam in the disruption era. An era marked by the rise of new media, namely alternative media, which in its development has become a new field of religious discourse debate. The debate about Hadith also found its momentum increasingly dynamic. For instance, Muslims in Indonesia use new media to access and make hadith as a lifestyle reference. The emerging of terms such as halal food, syar'i heads carves, halal tourism, ojek syar'i, prophet-style healing, and so on are some examples of them. Unfortunately the existence of this new media indirectly shifts the authority of the Ulama as a reference in understanding the sacred texts, including hadith. This shift emerges to fabrication and distortion of understanding. The contestation of the Hadits authority still revolves around the two main camps: textualism-fundamentalism on the one hand and moderate contextualist- on the other hand. Outside of the two mainstream, the Inkar Sunah group also colored the contestation of hadith authority in new media by middle-class Muslims. Although its voice was not as massive as the two previous groups.

\section{ABSTRAK}

Paper ini ditulis dengan tujuan untuk menjadi catatan awal tentang perdebatan hadis sebagai salah satu teks suci Islam di era disrupsi. Sebuah era yang ditandai dengan maraknya media baru, yakni media alternatif yang pada perkembangannya telah menjadi medan baru perdebatan wacana keagamaan. Perdebatan tentang Hadis pun menemukan momentumnya yang semakin dinamis. Sebagai contoh, Muslim di Indonesia memanfaatkan media baru untuk mengakses dan menjadikan hadis sebagai rujukan bergaya hidup. Lahirnya tema-tema seperti halal food, jilbab syar'i, wisata halal, ojek syar'i, pengobatan ala nabi, dan lain sebagainya adalah beberapaa contoh di antaranya. Sayangnya keberadaan media baru ini secara tidak langsung telah menggeser otoritas Ulama sebagai rujukan dalam memahami teks suci, temasuk hadis. Pergeseran ini melahirkan fabrikasi dan distorsi pemahaman. Kontestasi atas otoritas Hadis masih berkisar pada dua kubu mainstream: tekstualisfundamentalis di satu sisi dan kontekstualis-moderat di sisi lain. Di luar dari kedua kubu tersebut, kelompok Inkar Sunah juga ikut mewarnai kontestasi atas otoritas hadis di media baru oleh Muslim kelas menengah. Meskipun suaranya tidak semasif dua kelompok sebelumnya. 


\section{Pendahuluan}

Agama (dalam makna religi) hadir di tengah kehidupan manusia baik secara pribadi maupunn bersama-sama, dalam suasana interaksi sosial, ataupun dengan cara yang berbeda-beda. Inti dari religi berkaitan dengan keyakinan tentang keberadaan suatu kekuatan yang lebih tinggi dari manusia. Keyakinan terhadap agama tersebut disebabkan adanya beberapaa faktor. Pertama, bahwa perilaku manusia yang bersifat religi terjadi karena manusia mulai sadar akan adanya paham tentang jiwa (ruh). Kedua, gejala tersebut timbul karena manusia mengakui adanya banyak gejala yang tidak dapat dijelaskan oleh akal manusia. Ketiga, perilaku manusia dimaksudkan untuk menghadapi krisis - krisis yang ada dalam jangka waktu hidup manusia. Keempat, atau juga karena getaran atau emosi yang ditimbulkan dalam jiwa manusia sebagai akibat dari pengaruh dari pengaruh rasa kesatuan sebagai anggota dari suatu masyarakat. Dan kelima, perilaku manusia yang bersifat religi tersebut disebabkan manusia mendapat firman Tuhan.(20)

Faktor yang terakhir berhubungan erat dengan makna agama hari ini yang terkonsepsikan secara lebih sederhana. Agama dunia (world religion), aajarannya dibawa oleh seorang utusan, rasul, atau messiah yang diyakini oleh pemeluknya sebagai wakil Tuhan di bumi. Selain itu, agama-agama dunia meyakini adanya kitab suci sebagai pedoman dalam menjalankan aajaran agama tersebut. Tak terkecuali Islam, Islam adalah agama yang menganut paham tentang keberadaan Allah sebagai Tuhan, meyakini Muhammad sebagai utusan Allah dan al-Qur'an sebagai kitab suci yang diimani.

Di dalam keyakinan orang Islam keberadaan kitab suci atau sumber norma tertulis memiliki kedudukan tersendiri. Sumber normatif yang biasa dijadikan rujukan adalah al-Qur'an dan hadis. Sesungguhnya selain keduanya, juga terdapat sumber lain seperti fatwa sahabat, syariat sebelum Islam (syar'u man qablanāa), maslahah mursalah dan ijtihad para Ulama. Namun dalam konteks ini al-Qur'an dan hadis menjadi penting untuk dilihat, melampaui yang lainnya karena keduanya telah terdokumentasi secara tertulis dan bahkan oleh umumnya umat Muslim diyakini sebagai kitab atau teks suci (scripture).

Berbeda dengan al-Qur'an, pro dan kontra seputar otentisitas dan otoritas hadis nabi sangat dinamis. Di antara penyebabnya karena hadis terdokumentasikan jauh lebih akhir di banding al-Qur'an. Selain itu jumlah ayat al-Qur'an tidak sebanyak hadis nabi. Ditambah lagi transmisi hadis melalui beberapaa dekade generasi periwayat hadis, menimbulkan kecurigaan oleh sebagaian kalangan yang dari awal bersikap skeptis terhadap hadis. Dari sini memunculkan perdebatan bahwa hadis nabi telah mengalami pemalsuan dan penyimpangan sedemikian rupa. Bahkan oleh sebagaian kalangan dianggap sebagai produk rekayasa sejarah. Sebut saja misalnya pemikiran Ignác Goldziher dengan historisitas hadis nabi(12); teori Joseph Schacht dengan ide projecting back (26); atau pemikiran Zakaria Ouzon yang lebih banyak mengkritik dan mempertanyakan hadis-hadi yang terdapat di dalam kitab Shahih Bukhari(24).

Perdebatan seputar otoritas hadis nabi sebagai sumber hukum Islam sesungguhnya sudah banyak dibahas oleh para pakar hadis dan kesarjanaan pada era yang lebih akhir. alSyafi'i sebagai Ilmuwan penyandang gelar nāshir al-sunah telah gambalang memaparkan keberadaan hadis sebagai sumber otoritatif dalam beberapaa magnum opus-nya. Di dalam al-Risalah (7) atau Jima' al-'ilm (6) ia mendedah keberadaan hadis sebagai teks sakral (scripture) disamping alQur'an. Darinya muncul konsepsi tentang adanya kesamaan antara hadis dan Sunah. Pada generasi yang lebih akhir, Muhammad Abu Syahbah dan Musthafa al-A'dzami adalah dua pakar hadis yang juga ikut ambil menetralisir persoalan perdebatan tentang otoritas hadis tersebut. Di tengah tuduhan ketidakvalidan hadis yang dilontarkan oleh sebagaian orientalis, keduanya mendokumentasikan pembelaannya terhadap sunah nabi melalui karyanya yang berjudul Difa' an al-sunah wa raddu Syubahu alMusytasyrikin wa al-Kitab al-Mu'asyirin (27) dan Dirasat fi al-Hadits al-Nabawi wa al-Tarikh tadwinihi.(11) 
Sedangkan studi tentang otoritas hadis Nabi yang dilakukan oleh kesarjanaan di Barat pada era yang lebih baru dapat ditelaah dalam studi yang dilakukan oleh Aisyah Y. Musa dalam Hadith as Scipture: Discussions on the Authority of Prophetic Traditions in Islam.(23) temuan Musa tentang kontestasi otoritas hadis nabi di tengah masyarakat Muslim yang terus menggejala menjadi pijakan penting untuk melihat lebih lanjut bagaimana perkembangannya di era yang lebih dinamis ini. Musa tidak hanya mengupas perdebatan otoritas hadis nabi sebagai sumber hukum Islam pada periode klasik, melainkan mengkajinya pada era digital atau dunia internet dan media sosial. Hanya saja penelitian yang dilakukan oleh Musa bisa saja mengalami perkembangan atau bahkan perubahan. Mengingat data-data digital dapat berubah begitu cepat hanya dalam hitungan menit, bahkan detik. Akan tetapi temuan Musa menjadi sangat penting sebagai triger untuk penelitian-penelitian selanjutnya.

Studi tentang otoritas hadis memang sudah banyak dikaji oleh para pakar. namun pada konteks dan ruang yang berbeda, sebagaimana telah diutarakan oleh Musa, studi tentang otoritas hadis masih menyisakan pertanyaan lanjutan. Misalnya, bagaimana masyarakat yang terpisah jauh, dengan tradisi kenabian, baik dari dimensi ruang maupunn waktu, memperlakukan atau memposisikan hadis nabi. Masyarakat yang hidup di era digital misalnya, punya cara tersendiri untuk berinteraksi dengan kitab sucinya. Begitu pula dengan penerimaan, respon, atau ekspresi mereka atasnya. Artikel ini mengetengahkan analisis tentang persoalan tersebut dengan secara lebih khusus menitikberatkan pada posisi atau kedudukan hadis nabi bagi masyarakat Muslim kelas menengah di Indonesia. Tulisan ini melakukan telaah atas perlakuan kelas menengah muslim Indonesia terhadap hadis melalui media baru yang kian menjamur. Ringkasnya, tulisan ini hendak menunjukkan kontestasi atas otoritas hadis nabi yang terjadi di tengah masyarakat tersebut, sebagai bagian dari kelas sosial yang lebih terlihat menonjol dalam hal ekspresi keagamaan dibandingkan kelas sosial yang lain. Kelas menengah muslim, di samping ditandai dengan pendapatan tertentu, juga ditandai dengan sikap mereka yang begitu aware dengan norma agama. Kendati pada beberapa kasus, kepedulian terhadap norma agama tersebut tidak selalu sebagai bentuk respon yang positif. Alih-alih dapat meningkatkan syiar Islam, malah yang terjadi justru sebaliknya.

Tulisan ini dianggap penting untuk dibahas, berangkat dari asumsi awal, bahwa tantangan era post-truth (era pasca kebenaran) dan era disrupsi yang berimplikasi ke dalam berbagai lini kehidupan, telah merambah kepada perubahan sosial yang signifikan, temasuk cara dan ekspresi beragama masyarakat. Di era post-truth kebenaran atau fakta objektif dikelabui dengan kebohongan-kebohongan yang terus menerus diopinikan sehingga dapat mudah diterima oleh publik. Kondisi semacam itu tidak menutup kemungkinan melahirkan berbagai dinamika ekspresi dan sikap beragama yang semakin kompleks. Maka, potret kontestasi atas hadis nabi sebagai sumber otoritatif dalam beragama menjadi sangat penting untuk diketahui lebih jauh. Mengingat hadis nabi adalah referensi beragama umat Islam selain al-Qur'an.

\section{Review Tinjauan Pustaka}

\section{Otoritas Hadis Hadis Nabi}

Perbincangan tentang otoritas hadis tentu tidak dapat dilepaskan dari otentisitas hadis nabi itu sendiri. Otentisitas atau validitas hadis nabi merupakan isu sentral yang telah banyak dikaji oleh para ahli. Sejak pertengahan abad 19, perhatian para Orientalis telah mengarah pada persoalan tersebut. Gustav Weil (1848) dan Aloys Sprenger (1861) oleh Hallaq dianggap tokohtokoh yang menaruh perhatian tentang hadis nabi meskipun belum sekritis para tokoh era setelahnya. Kajian secara kritis terhadap hadis nabi semakin popular di dalam kajian keislaman di tangan Ignaz Goldziher dan Joseph Scahcht melalui karya menu mentalnya. (13)

Pasca temuan Schacht (1950) tentang otentisitas hadis nabi yang telah memicu kontroversi, studi yang serupa juga semakin banyak dilakukan. Keberadaan para pengkaji setelahnya terdiri dari tiga kelompok. Kelompok pertama mencoba 
mengkonfirmasi temuan Scahcht dan Goldziher, kelompok kedua melakukan bantahan dan kelompok terakhir mencoba menengahi kedua kubu tersebut. Menurut Hallaq, kelompok pertama tersebut diwakili oleh John Wansbrough dan Michael Cook. Sedangkan Nabia Abbott, F. Sezgin, M. Azami Gregor Schoeler, dan Johan Fuck mewakili kelompok kedua. Kelompok penengah di antara ketiganya diwakili oleh Harald Motzki, D. Santillana, G.H. Juynboll, Fazlurrahman, dan James Robson.(13)

Jika mundur jauh ke belakang, lahirnya perdebatan otoritas hadis nabi menurut sebagaian kalangan merujuk pada periode Sahabat, dimana terdapat dua riwayat hadis yang secara tersurat memerintahkan untuk menulis hadis, sekaligus perintah untuk menghapusnya. Kontradiksi seputar penulisan dan penghapusan hadis nabi tersebut Sebenarnya telah banyak di ulas oleh para ahli hadis seperti Imam Syafi'i dalam al-Umm, al-Risālah, dan Jimā' al-ilm serta Khatib al-Baghdadi dalam taqyīd al-Ilmi. Periode ini menurut Imam Syafi'i adalah periode dimana kelompok pengingkar sunah belum menggejala, sebagaimana pada periode selanjutnya, yakni kira-kira pada masa Bani Abasyiah. Keberadaan mereka lebih diidentifikasi sebagai pendapat perseorangan, bukan aspirasi dari suatu kelompok tertentu. Uraian tentang hal ini dapat ditelusuri pada kitab al-Umm karya Imam Syafi'i pada bab hikayāt al-qoul atthäifah allati raddat al-akhbār.(8)

Meskipun begitu, riwayat seputar perintah dan larangan menulis hadis tersebut tidak dapat dianggap remeh karena faktanya, pada periode-periode lebih akhir, hal tersebut selalu dijadikan pijakan para kelompok pengingkar sunah. Mereka berargumen bahwa tidak mungkin antara satu hadis dengan yang saling bertentangan. Belum lagi jika dikaitkan dengan keberadaan al-Qur'an yang diyakini sebagai al-Furqān (pembeda), tibyānan likulli syaiin (penjelas atas segala sesuatu) yang dianggap sudah final dan tidak lagi memerlukan sumber lain.

Usaha untuk menetralisir perdebatan seputar otoritas hadis nabi sebagai hukum Islam juga telah dilakukan oleh generasigenerasi setelahnya seperti, Ibnu Qutaibah dalam ta'wìl mukhtalaf al-hadìts, Ja'far Al-
Tahawi (w. 321 H.) dalam Musykil al-atsār, Ibnu Faruk (w. 406 H.), bayan musykil alhadìts. Kitab-kitab tersebut memuat penjelasan dan berbagai metode untuk mengatasi berbagai hadis yang seolah-olah kontradiktif antara satu dengan yang lain ataoun hadis-hadis yang mengesankan bermasalah baik dari aspek sanad maupunn matn. Dari kitab-kitab itu pula lahirlah kajian mendalam dengan melihat sisi historis (asbab wurūd al-hadīts), melihat konteks sosial masyarakat, serta aspek-aspek keilmuan lainnya.

Meskipun usaha untuk meneguhkan bahwa sunah memegang otoritas dalam hukum Islam di luar al-Qur'an, faktanya hal tersebut tidak menyurutkan sebagaian kelompok untuk menihilkan keberadaan sunah. Para pengingkar sunah dengan berbagi bentuknya terus tumbuh dan berkembang dengan cara dan pola yang berbeda-beda. Yang paling menonjol dari sekian tokoh inkar sunah adalah Mahmud Abu Rayyah. Adhwa' 'ala sunah al-Nabawiyah yang ditulis olehnya menuai kritik dari para sarjana muslim. Buku-buku bantahan atasnya pun bermunculan. Abu Syuhbah menulis Difa' an al-sunah wa raddu Sybahu alMusytasyrikin wa al-Kitab al-Mu'asyirin (27) dan Al-Ma'limi menulis Al-Anwar al-Kasyifah lima fi Kitab Adzwau 'ala Sunah min al-Zalal wa al-Tadzlil wa al-Mujazafah (4) sebagai bantahan atas tuduhan yang dilontarkan oleh Abu Rayah .

Pasca karya Mahmud Abu Rayyah dengan dinamika yang menyertainya, para kesarjanaan Islam kontemporer yang memiliki pemikiran moderat mencoba menengahi persoalan otoritas hadis nabi dengan menempatkan dan memperlakukannya secara proporsional. Hal itu sekaligus sejalan dengan berbagai tantangan dunia modern, yang menuntut adanya pengembangan dan kontekstualisasi pemahaman sehingga otoritas sunah tetap relevan sebagai landasan hukum Islam. Mereka adalah Al-Qarafi, Mahmud Syaltut, Yususf al-Qradhawi yang melahirkan konsep tentang tasyri'iyyah dan ghair tasyri'iyyah (5); Muhammad Syahrur dengan konsep sunah al-risālah, sunah al-nubuwwah (28); dan Syah Waliyullah al-Dihlawi dengan kaidah tablīgh al-risālah, ghair tablīgh alrisālah (2). Dari semua konsep yang 
ditawarkan hampir bisa ditarik benang merah bahwa konsepsi sunah yang ditawarkan oleh mereka memiliki kedekatan substansial, yakni melihat sosok nabi sebagai manusia yang tidak hanya memiliki peran tunggal melainkan nabi sebagai sosok yang multi dimensi dan menjalankan beragam peran. Nabi sebagai kepala keluarga, sekaligus sebagai kepala negara. Beliau juga sebagai pemberi fatwa (mufti) ataupun juga sebagai hakim maupunn qadhi. Bahkan nabi dalam beberapaa peristiwa mengakui sebagai manusia biasa, yang bisa jadi dalam urusan keduniaan tidak semua diketahui olehnya. Dari konsep ini kemudian melahirkan konsep sunah yang mutlak harus diikuti dan sunah yang bersifat universal, lokal, maupunn temporal yang tidak selamanya harus diikuti secara mutlak. Pandangan ini juga dapat dibaca di dalam pemikiran Syuhudi Ismail.(18)

\section{Dualitas Kewahyuan}

Perdebatan seputar otentisitas sekaligus otoritas hadis nabi tidak dapat dilepaskan dari persoalan dualitas kewahyuan (duality of revelation). Dualitas wahyu telah menjadi doktrin penting dalam tradisi Islam, khususnya di dalam tradisi Sunni. Pandangan ini dapat dijumpai pada kitab-kitab awal yang memaparkan konsepsi hukum Islam seperti karya Ibn Hazm al-Andalusi, di dalam alIhkam fi Ushul al-Ahkam (1983), ataupun juga pada kitab-kitab ushul al-fiqh lain yang banyak menerangkan tentang sumber-sumber perumusan dan kaidah hukum Islam.

Dualitas kewahyuan bermakna tidak hanya al-Qur'an saja yang dianggap sebagai wahyu dari Tuhan tetapi juga hadis. Dalam sudut pandang Musa, sebagaimana ia mengutip pandangan al-'Alwani, al-Qur'an adalah wahyu yang terbaca (recited revelation/wahy matlu') yang dengan kemu'jizatannya merupakan serangkaian susunan bacaan bersumber dari Tuhan langsung. Sedangkan hadis juga merupakan wahyu dari Tuhan, hanya saja reaksi bacaannya timbul dari Nabi (non-recited revelation/ wahy ghayr matlu'). Pandangan seperti ini menurut Musa, menjadi pandangan mayoritas umat Muslim kala itu.(23). Selain itu, nabi diyakini sebagai sosok yang ma'shum sekaligus tidak mungkin berkata dan berbuat atas dasar hawa nafsunya semata.

Di luar dari aspek tersebut, keberadaan hadis nabi memiliki kedudukan yang penting bagi umat Islam. Otoritas hadis nabi juga timbul tidak lepas dari faktor-faktor lain. Faktor-faktor yang menjadikan sunah nabi memiliki otoritas di antaranya, dinilai lebih praktis ('amali), detail (tafsili) dan komplit (syumuli). Selain mengandung aajaran yang kompleks dalam hal aturan kehidupan sehari hari, hadis nabi juga memberikan penjelasan yang rinci terkait norma atau prinsip umum yang tertuang di dalam al-Qur'an.(1)

Lahirnya model tafsir bil-ma'tsūr atas alQur'an juga merupakan bukti kuat bahwa Muslim generasi awal memposisikan hadis nabi sebagai penjelasan yang otoritatif atas wahyu al-Qur'an, sebelum mereka menggunakan akal ataupun piranti yang lainnya. Bahkan hingga hari ini tidak sedikit para ulama yang berpegang teguh pada penafsiran yang hanya bersumber dari riwayat-riwayat para sahabat yang valid saja.

\section{Hadis sebagai Teks Suci (Scripture)}

Selanjutnya, konsep duality of revealeation kemudian berimplikasi pada perlakukan masyarakat Muslim terhadap hadis nabi. Meskipun secara teks hadis nabi tidak disucikan atau dikeramatkan sebagaimana al-Qur'an namun tetap memiliki tempat tersendiri di dalam kehidupan umat Muslim. Konsep tentang hadith as scripure atau hadis sebagai kitab suci pun tidak dapat terelakkan.

Dalam penelitian ini, bisa saja terjadi karena apa-apa yang telah diwahyukan kepada Nabi terdiri dari dua bentuk. Pertama, sesuatu yang yang sudah paten (taken for granted), yang diamanahkan oleh Allah dan tidak bisa diubah lagi. Artinya nabi hanya menyampaikan sebagaimana yang diwahyukan oleh Allah. Ataupun yang kedua, Allah memberi peluang kepada nabi atas sesuatu tersebut untuk memutuskan (berijtihad) sesuai kapasitasnya. Dengan berpedoman bahwa nabi adalah manusia yang ma'shüm, maka ijtihad yang dilakukan oleh nabi adalah sesuatu yang wajar dan tidak melanggar norma Islam, tidak sebagaimana yang dikhawatirkan oleh para pengingkar hadis atau Ahlu al-Quran. 
Dengan kata lain, kesakralan yang melekat pada hadis nabi bukanlah kesakralan tekstual melainkan kesakralan dari konten atau isi yang terkandung di dalam hadis tersebut. Penjelasan mengenai keberadaan corak Islam yang merupakan perpaduan dari aajaran yang tertuang di dalam al-Qur'an maupunn hadis dapat ditelaah lebih jauh dalam karya Jorge Tharabisyi (18).

Ada beberapaa bukti yang menguatkan bahwa tekstualitas hadis sangat dipegangi oleh sekelompok umat Muslim. Seperti Komunitas Jama'ah tabligh di Pakistan sebagaimana temuan Metcalf. Komunitas Jama'ah tabligh telah menjadikan kitab-kitab yang berisikan hadis dan berbagai seluk beluk kehidupan nabi semacam role model dan cara pandang dunia. Menurutnya, Nalar tekstual mereka atas hadis mampu membawa perubahan yang signifikan dalam melawan hegemoni budaya asing yang dianggap bertentangan dengan gaya hidup Islami. (22) Beberapaa bukti lain seperti temuan Adis Duderija juga menyatakan bahwa Ahlu sunah wal-Jama'ah lahir atas sikap tekstualisme terhadap hadis nabi dan kemudian pada perkembangan selanjutnya melahirkan gerakan mainstream dan ekslusive. Begitu juga dengan penelitian Jonathan Brown dan Yasin Dutton yang mengemukakan temuan yang serupa (14).

Dengan demikian the living hadith atau sunah adalah bukti nyata bahwa hadis nabi menjadi gaya hidup oleh sebagaian masyarakat Muslim. Artinya tidak hanya the living Qur'an yang membudaya dan menjadi kebiasaan masyarakat, melainkan juga the living hadith. Bahkan the living hadith jauh melampaui the living Qur'an dengan alasan bahwa Nabi dianggap paling patut dicontoh berperilaku dalam wujud yang sudah aplikatif dan praktis dibanding Al-Qur'an. Keberadaan hadis telah menyatu dengan kehidupan masyarakat Muslim. Sebagaian ada yang menyadari dan tidak sedikit yang tidak menyadarinya. Dalam situasi yang terus berubah fenomena the living hadith tersebut juga semakin tidak terbaca dengan mudah. Artinya perubahan sosial telah membawa dampak yang signifikan dalam hal ekspresi keagamaan.

\section{III.Metodologi Penelitian}

Berdasarkan kesesuaian potensi data yang diperoleh, penelitian ini menggunakan metode etnografi virtual atau yang sering disebut dengan netnografi. Metode ini merupakan pengembangan dari studi antropologi yang menekankan deskripsi mendalam (thick description) tentang fenomena budaya. Yang membedakan dengan etnografi konvensional, objek material yang ditelaah di dalam netnografi adalah fenomena budaya yang ada di dunia internet. Meskipun kesan aktivitas di dalam internet adalah aktivitas maya, namun secara faktual, yang terjadi di dunia tersebut meninggalkan artefak budaya yang jauh lebih kompleks dibanding dunia nyata. Di antara penyebabnya adalah, perubahan yang begitu cepat karena berbasis pada kecerdasan buatan (artificial intelegent).

Sumber data diperoleh dari media online, baik berupa website, blog, ataupun media sosial, khususnya youtube dan facebook. Data diambil pada rentang waktu bulan agustus hingga desember tahun 2018.

\section{IV.Hasil dan Diskusi}

\section{Era Disrupsi dan Dampak Media Baru terhadap Perubahan Sosial Keagamaan}

Era disrupsi melahirkan berbagai perubahan sosial yang berdampak ke berbagai lini kehidupan. Era Disrupsi menuntut siapa saja untuk mampu bersaing dan mengikuti ritme yang terus berjalan secara dinamis. Antara satu dimensi dengan dimensi yang lain, baik sosial, ekonomi, maupun budaya terus semakin berkelindan. Memang, awalnya era disrupsi identik dengan berbagai kontestasi perkembangan teknologi yang berimplikasi secara ekonomi. Namun lambat laun, hal tersebut telah merambah pada sudut pandang masyarakat di dalam berkehidupan sosial, temasuk sikap beragama. Disrupsi tidak hanya berhubungan dengan berbagai perubahan-perubahan dalam aktivitas perekonomian yang mengharuskan pelaku ekonomi untuk berpikir dengan sudut pandang 'esok hari', melainkan juga erat kaitannya dengan berbagai tantangan kehidupan sosial masyarakat.

Jika diilustrasikan, situasi zaman disrupsi adalah munculnya berbagai fenomena yang 
bergerak begitu cepat dan terus mengalami perubahan yang sulit untuk dikejar. Oleh karena itu, sebagaimana ditegaskan Renald Kasali, disrupsi sesungguhnya tidak hanya fenomena hari ini melainkan fenomena hari esok yang dibawa ke hari ini. (19)

Jika dalam ranah ekonomi, era disrupsi menjadi tantangan untuk dapat dikejar dan diikuti serta disesuaikan, di dalam ranah beragama, era disrupsi juga tidak kalah memiliki tantangan tersendiri. Cara pandang masyarakat di era disrupsi teknologi yang lebih techno-minded, menjadikan mereka lebih sering mengambil jalan pintas dan praktis dalam hal memahami agama. Model pemahaman agama dengan potong kompas ini secara tidak langsung telah menihilkan beberapaa tahapan penting dalam memahami agama. Seperti, melakukan penelusuran sumber yang otoritatif, melakukan klarifikasi atau tabayyun, dan meniadakan proses keberulangan. Ketiganya menurut penulis adalah sebuah keharusan ketika seseorang mempelajari agama. Jika tidak yang terjadi adalah distorsi pemahaman dan kedangkalan berpikir.

Dalam teori Religious-social Shaping of technology yang dikemukakan oleh Heidi Campbell dalam bukunya When Religion Meets New Media (2010), ia menyatakan bahwa keberadaan media sebagai bentuk manifestasi dari teknologi berdampak tidak hanya pada aspek sosial politik ekonomi melainkan juga dapat merubah cara berpikir, perumusan fatwa-fatwa, ekspresi keagamaan ataupun hubungan sesama manusia yang terjalin atas dasar norma agama (10). Hal ini tentu dapat menjadi peluang sekaligus tantangan bagi kehidupan keagamaan hari ini.

Secara lebih sederhana, implikasi yang ditimbulkan dari era disrupsi di antaranya adalah problem pemahaman agama, pergeseran otoritas keagamaan, dan perubahan pola perilaku masyarakat. Pertama, Dalam hal pemahaman keagamaan, masyarakat milenial tidak lagi seperti masyarakat tradisional yang memiliki keterbatasan akses terhadap informasi. Era disrupsi teknologi menjadikan siapa saja tanpa melihat jenis kelamin dan kematangan usia dapat menjadi konsumen sekaligus produsen dari informasi keagamaan. Hal ini patut diwaspadai karena dapat menimbulkan pemahaman agama yang tanpa kontrol. Biasbias pemahaman terjadi dimana-tanpa tanpa adanya proses verifikasi dan dialog sebagaimana yang terjadi pada situasi Muslim tradisional. Tak ajarang pula dari implikasi ini melahirkan kelompok Muslim yang terkesan eksklusif dan tidak permisif terhadap keragaman pemahaman agama. Mereka 'alergi' dengan corak pemahaman agama di luar dari yang diyakininya.

Kedua, ketika masyarakat menghadapi reduksi pemahaman agama tanpa kendali, pada saat yang sama keberadaan media menjadikan otoritas keagamaan bergeser dari personal kepada impersonal. Artinya, keberadaan para pemegang otoritas, yakni orang-orang yang dianggap mumpuni dalam urusan agama (seperti Kiyai, Ustad, ataupun Tokoh agama) tidak selalu menjadi rujukan sebagaimana Muslim tradisional karena setiap orang dapat memilih sumber pengetahuan agama sesuai dengan kebutuhan dengan sangat mudah. Pergeseran dari personal kepada impersoanal juga menghilangkan interaksi sosial yang sesungguhnya dapat menghadirkan suasana tersendiri dalam proses belajar agama.

Ketiga, era disrupsi telah banyak mengubah pola perilaku masyarakat, khususnya melalui perantara media baru. Media baru telah memberi wawasan baru bagi masyarakat untuk bertindak sesuai dengan yang diperoleh dari media tersebut. Media sosial adalah faktor yang paling dominan yang paling banyak memberikan pengaruh dalam pola kehidupan masyarakat. Standar kepatutan pun tidak lagi sama antara satu orang dengan yang lainnya. Masyarakat membuat rumusan-rumusan kepatutan dalam berperilaku sesuai dengan apa yang dicerna dari media.

Bagaimanapun keberadaan media baru tetap tidak bisa diabaikan dalam kehidupan Muslim hari ini. Keberadaannya seolah telah menjadi kebutuhan dasar yang menempati posisi primer dalam kehidupan sehari-hari. Sayangnya media baru dengan karakteristiknya yang praktis dan multitasking telah banyak mempengaruhi bagaimana beragama maupunn memperlakukan sumber-sumber agama. Media baru ini secara tidak langsung menjadi agen transformasi berbagai model beragama 
yang hidup di tengah-tengah masyarakat. Di satu sisi, dengan adanya media baru masyarakat agama dimudahkan dalam hal akses terhadap sumber-sumber nilai agama, namun di sisi yang lain perlu kewaspadaan karena sumber yang diambil tidak selalu valid dan otoritatif.

\section{Respon Kelas Menengah Muslim Indonesia atas Norma Agama}

Menyoal kelas menengah tentu berkaitan erat dengan tingkatan sosial yang ada di dalam suatu masyarakat. Kelas menengah biasanya berhubungan dengan aktivitas perekonomian yang dilakukan oleh masyarakat. Di Indonesia, lahirnya kelas menengah oleh sebagaian ahli, disebut-sebut merujuk pada era 80an, dimana era Orde baru berada pada masa kejayaannya. Era dimana aktivitas modernisasi dan globalisasi mulai tampak di berbagai lini kehidupan $(16,17)$ Teori ini ada benarnya mengingat kondisi sosial dan politik sangat memiliki pengaruh terhadap cara pandang dan pola pikir manusia. Kekuasaan tunggal kala itu membawa perubahan yang signifikan dalam berbagai ranah kehidupan.

Kelas menengah di Indonesia, menurut Ansori juga tidak selalu ditentukan secara struktural, tetapi lebih pada proses produksi dan reproduksi yang berkelanjutan melalui praktik-praktik budaya kelas, ia berpendapat bahwa:

the new Indonesian middle class is not structurally pre-determined, but is in the continual process of production and reproduction through the cultural practices of class. In other words, ownership of economic and material resources does not automatically determine class; instead, culture and a lifestyle of consumerism must be seen as important cultural processes through which an emerging middle class actually creates itself as a sociocultural entity. The emerging new middle class, the primary product of the economic modernization and globalization policies of the New Order (1966-1997), is a prosperous and affluent group of people with a certain level of economic resources. However, they must be understood as a never-ending cultural project.(9)
Instrumen-instrumen perekonomian untuk menentukan kelas lebih dominan dibandingkan instrumen lain, seperti budaya dan agama. Meskipun begitu, kelas menengah di Indonesia memiliki keterkaitan kuat dengan agama. Hal tersebut tidak dapat dilepaskan dari fakta bahwa Indonesia adalah negara dengan populasi Muslim terbesar di dunia. Keberadaan umat Muslim tersebut menjadi entitas tersendiri yang menjadi penciri di antara masyarakat yang lain. Penyebabnya adalah bahwa ajaran agama telah menginspirasi tata cara berperilaku. Dari sini melahirkan satu tema baru dalam kelas sosial masyarakat di Indonesia, yakni Muslim kelas menengah (Middle class Muslim). Mereka adalah masyarakat yang melek informasi sekaligus memiliki daya beli serta memiliki pemahaman keagamaan yang cukup.

Kelas menengah Muslim memiliki ekspresi beragama yang khas. Sebagaimana sudut pandang Hasbullah, kelas menengah Muslim di Indonesia sebagai bentuk presentasi kultural. Di era 80an dan 90an menurut analisis Hasbullah, kelas menengah Muslim ditandai dengan lima hal, yakni, fenomena maraknya busana Muslimah, musik religi modern, berdirinya ikatan cendekiawan Muslim, penerbitan media Islam, dan pengajian elit di tempat-tempat modern.(15) Hal ini menegaskan bahwa kelas menengah Muslim tidak selalu sama dengan kelas sosial ekonomi. Kriterianya ditentukan dengan indikasi kultural sebagaimana yang dipaparkan dalam studi Hasbullah tersebut. Fenomena semacam itu juga berlaku hingga hari ini. Bahkan gerakan dan ekspresinya jauh lebih masif dan dinamis.

Senada dengan hal tersebut, kelas menengah Muslim menurut Yuswohadi adalah kelas sosial tertentu yang memiliki knowledgeable-modern, digital savvy, socially-connected, universalist-global minded, temasuk juga konsumtif. Di Indonesia kelas menengah Muslim ini adalah generasi yang lahir kisaran tahun 1980-an dan awal tahun 1990-an, yang telah mengalami berbagai formative experience. Pengalaman tersebut membentuk nilai-nilai dan perilaku mereka. Berbagai benturan pengalaman tersebut, seperti perubahan suasana sosial politik dari orde lama ke orde baru, kelahiran organisasi cendekiawan 
Muslim, krisis moneter, kebebasan ekspresi beragama pada era Gus Dur, kebebasan pers, berbagai aktivitas radikalisme yang mengguncang jagat internasional, juga revolusi dalam hal teknologi serta pesatnya media sosial.(29)

Secara lebih sederhana, ciri mendasar dari Muslim kelas menengah tentu tidak dapat dilepaskan dari dua entitas penting yakni masyarakat yang memiliki daya beli dan masyarakat yang religius. Mereka memiliki daya beli karena mereka adalah kelompok ekonomi kelas menengah yang tidak lagi kesulitan dalam hal ekonomi. Selain itu mereka mereka juga melek agama, atau memiliki pemahaman keagamaan, meskipun dalam arti lain pemahaman mereka seringkali kurang mendalam.(3)

Di era post konsumerisme Islam, perilaku konsumtif mereka dapat diidentifikasi ke dalam dua hal, yakni konsumtif secara material maupunn konsumtif secara spiritual. Secara material mereka terwakili dengan maraknya kemunculan tren pakaian yang berlabel Islami, produk baik barang maupunn jasa berlabel Islam. Adapun secara spiritual, ciri masyarakat Muslim kelas menengah dengan hadirnya berbagai kegiatan kerohanian yang dianggap sebagai wahana pemenuhan kebutuhan spiritual secara popular praktis (25).

Jika dilihat dari aspek medium, keberadaan technological determination atau determinisme teknologi, telah membawa masyarakat Muslim kelas menengah di Indonesia kepada cara-cara beragama yang dipengaruhi oleh peran kecanggihan teknologi, khususnya teknologi komunikasi elektronik. Teknologi komunikasi telah menjadi bagian penting dalam kehidupan manusia sehari-hari. Bahkan kehadirannya melebihi peran-peran manusia dalam kehidupan nyata. Hari ini mulai dari bangun tidur hingga tidur lagi aktivitas manusia lebih banyak dihabiskan untuk berinteraksi dengan teknologi informasi dan komunikasi.

Dari fenomena tersebut menimbulkan pergeseran otoritas keagamaan yang semula keberadaan Kiai, Ajengan, Tuan Guru atau tokoh agama menjadi rujukan dalam mempelajari agama dengan tahapan yang tidak singkat, kini fenomena tersebut bergeser. Fasilitas informasi keagamaan yang disediakan oleh kecanggihan teknologi menjadikan muslim kelas menengah mencari jalan pintas, dengan cukup mengandalkan gawai yang bisa diakses dengan mudah. Sayangnya karakter masyarakat kelas menengah muslim yang melek teknologi tidak dibarengi dengan kesadaran dan kejernihan berpikir dalam menerima informasi. Dalam banyak studi, yang terjadi justru salah paham dalam memahami agama. Informasi tentang pengetahuan agama yang diperoleh dari media online tanpa melalui proses filter dan konfirmasi yang ketat sehingga secara tidak langsung menerima informasi yang tidak valid. Dengan bergesernya otoritas keagamaan ini bergeser pula sudut padang dan sikap yang dimiliki oleh masyarakat kelas menengah muslim. Muslim kelas menengah yang dari awal telah bercirikan individual dan melek teknologi tampaknya dengan keberadaan medium yang begitu praktis memberikan kemudahan bagi mereka untuk cepat merasa puas dalam memahami agama, keberadaan sosok fisik seorang agamawan tidak lagi selalu penting. Lahirnya ustad dadakan, gerakan hijrah yang dimulai dengan gaya berpakaian, perilaku konsumtif yang dikemas dengan islami adalah imbas dari pergeseran otoritas tersebut.

Pola kehidupan keagamaan semacam ini juga melahirkan sikap beragama yang praktis dan pada saat tertentu dapat melahirkan sikap yang eksklusif dan tidak mudah menerima keragaman pemahaman. Cara beragama yang demikian ini tidak dapat dilepaskan dari proses memahami hadis nabi sebagai sumber normatif yang selalu dipegang teguh dalam kehidupan sehari-hari selain al-Qur'an.

\section{Kontestasi atas Otoritas Hadis di Era Disrupsi}

Kontestasi atas hadis nabi tidak berhenti pada era dimana hadis tersebut telah dibukukan dalam bentuk kanonisasi hadis. Era digital dan kecanggihan teknologi juga telah menjadi arena kontestasi dengan pola dan bentuk yang berbeda. Bahkan situasinya jauh lebih kompleks dan dinamis dibandingkan era dimana kecanggihan teknologi belum mengemuka. Hal tersebut tidak lain karena tidak adanya sekat dan batas antara orang orang yang menguasai ilmu 
agama dan tidak. Antara orang yang memahami hadis nabi beserta seluk beluknya dengan orang yang hanya bisa mengerti hadis nabi dari terjemahan yang didapat dari media sosial. Semua seolah sama dalam satu arena percaturan yang sulit untuk dibedakan, mana yang otentik dan mana yang tidak.

Berebut klaim atas tafsir terhadap hadis nabi menjadi gejala yang paling terlihat dalam fenomena ini. Kelompok tertentu dengan semangat untuk menghidupkan sunah dengan mudah mengikuti tren kehidupan yang religius dengan mengutip hadis nabi sebagai bentuk legitimasi tindakan mereka. Di saat yang sama kelompok lain justru melihat kemudahan ini menjadi permasalahan yang membahayakan karena proses transmisi dan pemahaman atas suatu hadis nabi tidak berjalan dengan cara yang semestinya.

Di era ini mudah sekali ditemui hadishadis nabi berseliweran di beranda media sosial ataupun perangkat media online lainnya. Orang-orang tidak lagi bersusah payah harus menelusuri kepada kitab-kitab induk untuk menemukan suatu hadis. Setiap orang juga memiliki akses yang terbuka untuk melakukan penafsiran dan pemahaman sesuai dengan kapasitas dan kemampuan yang dimiliki.

Bagi Muslim kelas menengah, hadis nabi menempati posisi yang begitu penting. Jargon kembali kepada al-Quran dan Sunah yang diwujudkan ke dalam berbagai perilaku berkehidupan adalah contoh yang nyata betapa strategisnya kedudukan hadis. Iklaniklan produk yang mensuplai kebutuhan gaya kehidupan ala nabi merupakan salah satu fenomena yang dapat dengan mudah dijumpai di berbagai platform media online. Contohnya adalah iklan tentang jual beli alatalat untuk olahraga sunah. Olahraga yang diciptakan sesuai sunah nabi adalah berenang, memanah, dan berkuda. Dengan kata lain fenomena ini telah ditangkap oleh pasar atau industri sebagai objek komoditas yang menguntungkan.

Sebagaimana ciri khasnya, kelas menengah sebagai kelas sosial, selain memiliki daya beli mereka juga menyandarkan perilaku atau aktivitas konsumsi mereka berdasarkan spirit dan norma agama. Mereka adalah kelas sosial yang melek teknologi sekaligus melek agama. Kelompok masyarakat ini selain tetap eksis di dalam kehidupan yang up to date sekaligus juga berkeyakinan tetap menyelaraskan gaya hidupnya dengan Sunah nabi.

Hal ini diperkuat dengan temuan Saputro (2015), bahwa bagi Muslim kelas menengah everyday Qur'an telah menjiwai dalam kehidupan sehari-hari. Kelompok masyarakat tersebut dalam tataran praksis selalu mengaitkan tindakannya dengan seruan alQur'an maupunn hadis. Hal ini juga dipertegas di dalam riset yang dilakukan oleh Alvara Research Center bahwa karakteristik Muslim kelas menengah memiliki entitas agamis. Menyandarkan aktivitas mereka pada al-Qur' an maupunn hadis (3)

Sebagaimana telah di ulas pada bagian awal tulisan ini, sejak awal, hadis nabi dianggap sebagai sumber normatif yang memantik perdebatan seputar otoritasnya. Mulai dari mempertanyakan otentisitasnya hingga cakupan otoritas hadis nabi sebagai pedoman. Dari sini melahirkan berbagai teori tentang sunah nabi baik yang dapat dijadikan sebagai rujukan maupunn yang tidak.

Pun juga dengan era disrupsi ini yang menampakkan fenomena yang begitu beragam. Dengan berbagai dinamika kehidupan sosial keagamaan yang semakin tidak terprediksi, masyarakat Muslim kelas menengah memperlakukan dan memposisikan hadis nabi dengan cara dan model yang berbeda-beda.

Perkembangan teknologi dan pemanfaatan media yang begitu masif juga menjadi faktor dominan dalam membentuk cara pandang masyarakat tentang hadis nabi. Jika dalam tradisi kaum santri lebih terbiasa dengan sumber teks-teks tulis yang berasal dari kitab-kitab ulama klasik, maka Muslim kelas menengah lebih sering memanfaatkan kemudahan teknologi untuk mengakses kepada sumber agama.

$\begin{array}{cccc}\text { Perebutan } & \text { atas } & \text { otoritas } & \text { hadis } \\ \text { sesungguhnya } & \text { dapat } & \text { dijumpai } & \text { dalam }\end{array}$ beberapaa kelompok komunitas agama yang sama-sama mengklaim pengikut sunah atau aajaran nabi. Komunitas yang dimaksud secara spesifik tidak berafiliasi pada satu kelompok Ormas Islam tertentu tetapi 
bermacam-macam. Mulai ormas Islam yang bercirikan puritanis ataupun yang bercirikan moderat. Dengan kata lain kontestasi atas otoritas hadis terjadi pada Ormas Islam Salafi, Wahabi ataupun pada Ormas Islam NU, Muhammadiyah sekalipun. Kelas menengah Islam ada di semua ormas tersebut. Penciri utamanya adalah mereka yang yang melek teknologi menempatkan agama sebagai norma yang penting dalam bergaya hidup.

Kontestasi atas otoritas hadis ditampilkan oleh kelompok pengusung gerakan nikah poligami. Komunitas ini dapat dikategorikan ke dalam kelompok puritanis. Ada beberapaa nama yang menandai kelompok ini. Namanama tersebut adalah Global Ikhwan, Dauroh Poligami Indonesia, ataupun Klub poligami Indonesia. Komunitas perempuan di dalam klub ini memiliki organisasi tersendiri yang diberi nama Klub Istri Taat Suami (KITS). Di Indonesia pertama kali kelompok ini dideklarasikan oleh Gina Puspita.(21) Jika dirunut mundur ke belakang, kelompokkelompok tersebut sampai kepada gerakan Islam Darul arqam yang yang pertama kali berdiri di Malaysia.

Kelompok ini menyuarakan pentingnya poligami sebab hal tersebut adalah perintah nabi dan menjalankan sunahnya. Komunitas ini meyakini bahwa melaksanakan poligami sebagai bagian dari melaksanakan sunah yang tidak banyak dilakukan umat muslim. Mereka menyebutnya sebagai (sunah matrukah). Hadis-hadis seputar pernikahan banyak dijadikan rujukan tindakan-tindakan mereka di dalam menyebarkan aajaran poligami.

Fakta yang lain, fenomena ini juga menunjukkan bahwa kelas sosial tersebut telah menjadikan hadis sebagai komoditas. Sebagai contoh, adalah pelatihan persiapan poligami yang diadakan oleh kelompok Dauroh Poligami Indonesia. Dengan pijakan norma hadis-hadis seputar pernikahan komunitas ini gencar melakukan promosi di berbagai di media sosial. Acara ini juga dibandrol dengan tarif tertentu dengan fasilitas tertentu. Menariknya, dengan terbuka mereka membuka kesempatan bagi laki-laki yang memiliki keinginan untuk menikah poligami.
Sikap masyarakat Muslim kelas menengah dalam merespon seruan hadishadis nabi tampaknya juga telah dimanfaatkan oleh para inisiator startup yang bergerak dibidang ekonomi. Mereka memanfaatkan peluang ini untuk menjadi lahan bisnis yang menguntungkan. Berbagai produk kemudian dilabeli halal, anti riba, dan sesuai dengan syari'ah.

Target dari pemilik modal tersebut adalah Muslim kelas menengah yang bercirikan tekstualis-skripturalis. Mereka adalah kelas menengah yang lebih terlihat mengamalkan aajaran Islam secara eksoterik. Yakni lebih mengedepankan aspek luar dan yang tampak dari aajaran agama. Bagi kelompok ini sunah sangat memiliki otoritas dalam berbagai lini kehidupan.

Di sisi lain, Muslim kelas menengah sesungguhnya tidak selalu terafiliasi pada Muslim yang memiliki kecenderungan tekstualis skripturalis atau dalam bahasa Saputro sebagai Salafi Wahabi (25) meskipun ini menurutnya baru sebatas asumsi yang terbuka untuk dikaji lebih lanjut. Muslim kelas menengah juga terdiri dari beragam varian dan model. Dengan mundur ke belakang, lahirnya organisasi Ikatan Cendekiawan Muslim Indonesia (ICMI) adalah contoh lain dari kelas sosial tersebut. ICMI adalah salah satu komunitas yang muncul di awal kelahiran Muslim kelas menengah. Mereka merupakan sekumpulan cendekiawan Muslim yang melek informasi dan akomodatif sekaligus adaptif terhadap berbagai pemikiran Islam yang progresif. Artinya keberadaan Muslim kelas menengah tidak selalu identik dengan kaum puritanis yang tekstual dan skriptural.

Pada konteks hari ini, komunitas Muslim kelas menengah juga mulai terlihat jati dirinya. Sebagaian dari mereka terafiliasi pada ormas besar di Indonesia, seperti NU, Muhammadiyah ataupun yang sejenis keduanya. Sebagai bentuk antitesa dari model gerakan Islam modern dan puritan, mereka menawarkan model pemahaman yang berbeda. Islam moderat, Islam nusantara, Islam wasathiyah, Islam berkemajuan adalah tagline yang biasa dipakai oleh komunitas tersebut sebagai bentuk alternatif pemahaman di luar kelompok puritan atau Islam modernis. 
Temuan penulis tentang betapa variannya kelas menengah muslim diperkuat dengan hasil riset yang dilakukan oleh Alvara Research center. Prosentase Muslim kelas menengah yang berafiliasi kepada ormas seperti Nahdhatul Ulama atau Muhammadiyahh jauh lebih banyak dibandingkan ormas yang lain.(3) Artinya, ekspresi keagamaan Muslim kelas menengah memiliki sangat beragam. Muslim kelas menengah juga tidak identik dengan ormas tertentu.

Di luar dari kedua kubu yang sama-sama mengklaim pengikut sunah, kelompok lain yang masih eksis adalah kelompok mungnkir sunah. Mereka adalah orang-orang yang berkeyakinan bahwa keberadaan nabi adalah penyampai wahyu yang berupa al-Qur'an. Hal-hal yang tidak ada di dalam al-Qur'an dianggap sebagai sesuatu yang tidak valid dan otentik. Mereka secara tidak langsung adalah kelompok yang menolak hadis nabi. Mereka dikenal sebagai Ahl Qur'an, Quranist, atau al-Qur'an alone.(23)

Bisa jadi, bagi kelompok ini hadis tidak lagi otoritatif karena dianggap sudah terpenuhi oleh berbagai aturan atau norma yang terkandung di dalam al-Qur'an. Memang kelompok mungkir sunah atau mungkir hadis di era disrupsi ini tidak secara terbuka menyatakan penolakannya atas hadis sebagaimana tokoh-tokoh penggagasnya semisal, Kasim Ahmad dari Malaysia, Taufiq Sidqi, Rashad Khalifah dan Ahmad Subhi Mansur dari Mesir, dan Edip Yuksel dari Turki. Namun dari berbagai pemahaman yang dipublikasikan di berbagai media sesungguhnya pandangan-pandangan mereka telah mengarah pada kelompok tersebut.

Sebagai contoh akan hal tersebut, kemunculan pengajian di Sukoharjo yang diketuai oleh Minardi Mursyid. FUI (Forum Umat Islam) yang bermarkas di Solo menentang secara keras aajaran yang dibawa oleh Minardi Mursyid tersebut. Perang argumentasi antara dua kelompok pun terjadi melalui media. Di tengah tuduhan dari kelompok luar Minardi Mursyid beserta para jama'ahnya tetap melakukan pengajian dan menyebarkan aajarannya temasuk melalui media baru. Ujung dari kontestasi ini adalah munculnya fatwa sesat terhadap kelompok pengajian tersebut dan akhirnya MUI pun juga turun tangan untuk memberikan fatwa yangs ama.

Memang gerakan Islam dari kelompok pengingkar sunah ini tidak semasif dari yang lainnya namun Keberadaannya cukup bisa mewarnai kontestasi atas otoritas hadis nabi yang diperagakan oleh kelompok Muslim kelas menengah. Dengan kata lain, hingga tulisan ini selesai ditulis, Indonesia masih menjadi lahan subur untuk berkembangnya berbagai ekspresi keagamaan, temasuk di antaranya bagaimana mereka memperlakukan dan menempatkan hadis nabi sebagai rujukan yang valid dan otoritatif.

\section{Kesimpulan}

Muslim kelas menengah sebagai representasi kelas sosial Muslim yang melek dengan berbagai kemajuan peradaban sekaligus peduli terhadap norma agama adalah fenomena yang tetap relevan untuk diteliti. Keberadaanya sesungguhnya tidak benar benar baru. Kemunculan Muslim kelas menengah diidentifikasi sejak masa orde baru. Namun kini semakin tampak menjadi fenomena yang khas karena kelas sosial tersebut terus berdinamika dan memiliki beragam ekspresi keagamaan yang terus berubah secara dinamis.

Keragaman ekspresi keagamaan tersebut tidak dapat dilepaskan dari sikap mereka terhadap sumber norma yang ada di dalam Islam. Secara lebih spesifik adalah hadis nabi. Kedudukan hadis nabi bagi kelompok tersebut begitu penting. Hadis telah menyatu dengan berbagai aktivitas keseharian. Maka tidak mudah untuk membedakan aktivitas mereka mana yang berdasarkan atas hadis nabi dan mana yang tidak.

Muslim kelas menengah rupanya juga tidak terdiri dari satu corak, melainkan bermacam-macam. Mereka tidak hanya terafiliasi pada kelompok Islam puritan tetapi juga berafiliasi pada Islam moderat sebagaimana yang disusun oleh NU maupunn Muhammadiyah. Corak tersebut dapat dikaitkan dengan pertalian antara komunitas tersebut dengan latar belakang ormas yang diikutinya. Dari sini melahirkan kontestasi atas otoritas hadis nabi dengan sudut pandang yang berbeda-beda. 
Kontestasi tersebut berlangsung di arena media baru. Wujud dari kontestasi tersebut adalah dengan berebut tafsir atas hadis-hadis yang dijadikan pijakan dalam kehidupan sehari-hari. Bagi mereka yang memiliki latar belakang Islam puritanis mereka mengekspresikan keagamaannya dengan model penafsiran yang kaku dan tekstual sedangkan bagi sebagaian lain yang memiliki latar belakang moderat mereka lebih terbuka terhadap perbedaan.

Meskipun kontestasi atas otoritas hadis nabi di era disrupsi ini begitu komplek melibatkan berbagai kalangan, kelompok atau komunitas-komunitas tertentu tapi mereka sama-sama meyakini keberadaan hadis nabi sebagai sumber yang otoritatif. Perbedaanya terletak pada bagaimana mereka memperlakukan hadis tersebut sebagai sesuatu yang otoritatif. Sebagaian kelompok melihatnya secara tekstual dan skriptural. Menerjemahkan apa-apa yang tertuang di dalam hadis nabi dengan tindakan yang praktis tanpa melihatnya lebih jauh ke dalam. Sedangkan kelompok yang lain, mengajak untuk bersikap lebih selektif dalam mengambil dan mempraktikkan hadis nabi. Sehingga otoritas hadis nabi sebagai sumber hukum Islam tetap relevan dan tidak terkesan dipaksakan.

Selain dari kedua kelompok mainstream tersebut, Muslim kelas menengah lain yang juga ikut mengemuka dalam berebut tafsir atas otoritas hadis Nabi adalah Munkir sunah (kelompok pengingkar sunah). Meskipun kelompok ini tidak semasif kelompok yang lain, di kancah media baru, ambil kelompok ini tidak dapat dipandang sebelah mata. Gagasan yang telah banyak digagas oleh tokoh-tokoh semisal Taufiq Sidqi atau Kasim Ahmad rupanya masih menyala hingga hari ini.

\section{Referensi}

1. Alamsyah. Otoritas Sunah Nabi sebagai Sumber Hukum Islam di Dunia Modern. SOSIO-RELIGIA 9, 2010.

2. Al-Dihlawi SWI 'Abd A-R. Hujjatullah al-Balighah. 1st ed. Cairo: Dar al-jeil, 2005 .

3. Ali H, Purwandi L. INDONESIA MIDDLE CLASS MUSLIM: Religiosity and
Consumerism. Jakarta: Alvara Research Center, 2017.

4. Al-Ma'limi 'Abdurrahamn bin Yahya. Al-Anwar al-Kasyifah lima fi Kitab Adzwau 'ala Sunah min al-Zalal wa al-Tadzlil wa al-Mujazafah. Beirut: Al-Maktabah alSalafiyyah, t.t.

5. Al-Qaradhawi Y. Kaifa Nata'ammal ma'a al-Sunah al-Nabawiyyah. Kairo: Dar alSyuruq, 1992.

6. Al-Syafi'i M bin I. Jima' al-Ilm. Haram: Maktabah Ibn Taimiyah, t.t.

7. Al-Syafi'i M bin I. Al-Risalah. Mesir: Maktabah al-Halabi, 1940.

8. Al-Syafi'i M bin I. Al-Umm. Mansoura: Dar al-Wafa, 2001.

9. Ansori MH. Consumerism and the Emergence of a New Middle Class in Globalizing Indonesia. Explorations a Graduate Student Journal of Southeast Asian Studies 9: 87-97, 2009.

10. Campbell H. When Religion Meets New Media. Routledge, 2010.

11. al-A'dzami MM. Dirasat fi al-Hadits alNabawi wa al-Tarikh tadwinihi. Beirut: AlMaktab al-Islami, 1980.

12. Goldziher I. Muslim Studies. Aldine Transaction, 2006.

13. Hallaq WB. The Authenticity of Prophetic Hadith: Pseudo Problem. Studia Islamica 89: 5-90, 1999.

14. Hasbillah A 'Ubaydi. Nalar Tekstual Ahli Hadis Dalam Ormas Modernis dan Tradisionalis Islam di Indonesia. UIN Syarif Hidayatullah Jakarta: 2017.

15. Hasbullah M. Teori Habitus dan Kelas Menengah Muslim Indonesia. KHAZANAH, Jurnal Ilmu Agama Islam 3, 2007.

16. Hasbullah M. Cultural Presentation of the Muslim Middle Class in Contemporary Indonesia. Studi Islamika Indonesian Journal for Islamic Studies 7, 2009.

17. Hefner RW. Islam, State, and Civil Society: ICMI and the Struggle for the Indonesian Middle Class on JSTOR. Indonesia : 1-35, 1993. 
18. Ismail MS. Hadis Nabi yang tekstual dan kontekstual: telaah Ma'ani al-Hadits tentang aajaran Islam yang universal, temporal, dan lokal. Bulan Bintang, 1994.

19. Kasali R. Meluruskan Pemahaman soal "Disruption" [Online]. KOMPAS.com: 2017.

https://bisniskeuangan.kompas.com/read/20 17/05/05/073000626/meluruskan.pemaham an.soal.disruption. [30 Sep. 2018].

20. Koentajaraningrat. Beberapaa pokok antropologi sosial. 7th ed. Jakarta: Dian Rakyat, 1990.

21. Linda H. Gina Puspita: 'Poligami Tidak Menentang Fitrah Manusia' [Online]. muslimdaily.net: [date unknown]. http://www.muslimdaily.net/artikel/opini/gi na-puspita-poligami-tidak-menentangfitrah-manusia.html [1 Jul. 2018].

22. Metcalf BD. Living Hadith in the Tablighi Jama' at. The Journal of Asian Studies 52: 584-608, 1993.

23. Musa AY. Hadīth as scripture: discussions on the authority of prophetic traditions in Islam. Palgrave Macmillan, 2008.
24. Ouzon Z. Jinayah al-Bukhari. Beirut: Rias El-Rayyes Books, 2004.

25. Saputro ME. Everyday Qur'an di Era Post-Konsumerisme Muslim. Mutawâtir: Jurnal Keilmuan Tafsir Hadis 5: 179-200, 2015.

26. Schacht J. The origins of Muhammadan jurisprudence. Clarendon Press, 1950.

27. Syahbah MA. Difa' an al-sunah wa raddu Sybahu al-Musytasyrikin wa al-Kitab alMu'asyirin'. Cairo: Mujamma' al-Buhuts al-Islamiyyah, 1985.

28. Syahrur M. Al-Kitab wa Al-Qur'an; Qiraah Mu'ashirah. Damaskus: Al-Ahali, 1992.

29. Yuswohadi. KelasInspirasi \& Bukber Memberi: "Gen M" [Online]. yuswohady.com: 2018. http://www.yuswohady.com/category/midd le-class-moslem/ [1 Oct. 2018]. 